\title{
Trick or treat? Muslim Thangals, psychologisation and pragmatic realism in Northern Kerala, India
}

\author{
Claudia Lang \\ Ludwig-Maximilians-University
}

\begin{abstract}
Thangals are an endogamous community in Kerala, India, of Yemeni heritage who claim direct descent from the Prophet Muhammad's family. Due to their sacrosanct status, many thangals work as religious healers and thus are part of the informal mental health care system in Northern Kerala. Using the case of one thangal healer as an illustration of the many ritual healers in Kerala who engage the modern discourse of psychology in their practices, I argue that the psychologisation of ritual healing is part of a wider trend: the increasing rationalisation and scientification of traditional medical practices, whereby an increasing number of traditional healers negotiate science, modernity and religion and position their practice within these contested fields. Based on the analysis of this thangal's healing practice in the local context of Northern Kerala, I further argue that in order to understand "ritual" healing, scholars should emphasise pragmatic realism more than doctrinal purity.
\end{abstract}

\section{Keywords}

mental health, pragmatic realism, psychologisation, ritual healing, South Asia, Thangals

Mental health care in the southern Indian state of Kerala consists of various formalised and nonformalised medical and religious practices. Both biopsychiatry and Western psychology strongly influence professional and lay discourses on mental illness. Patients and their families also use Ayurveda, homeopathy and naturopathy in both their institutionalised and noninstitutionalised configurations, and seek additional help through religious healing, be it Muslim, Hindu, or Christian. In the largely Muslim Malappuram and Kozhikode districts of

\section{Corresponding author:}

Claudia Lang, Institute of Social and Cultural Anthropology, Ludwig-Maximilians-University, Oettingenstr. 67, 80538 Munich, Germany.

Email: Claudia.lang@ethnologie.Imu.de 
Malabar, Northern Kerala, it is thangals, ${ }^{1}$ Muslim healers, to whom many Muslims with mental distress or mental illness turn to either before, after, parallel to, or instead of seeking another medical treatment.

In this paper, I draw upon what Tarabout (1999) has called the "psychologisation" of religious or cosmological healing and its translation into "indigenous forms of psychotherapy" (Tarabout, 1999, p. 133). With regard to mental health, most medical professionals and lay people express the legitimacy and efficacy of religion and spirituality in psychological terms. Significantly, many religious and spiritual practitioners themselves understand and express religious healing within a psychological framework. Using the case of one thangal healer, ${ }^{3}$ the aim of this paper is to analyse the psychologisation of the healing practices of thangals in Malabar, Kerala. It examines thangals' position in a social context that is characterised by the hegemony of the biopsychiatric and psychological discourse in which ritual healing practices are largely devalued and assessed as mere superstitions to be overcome on the way to modernity. At the same time, however, there exists an increasing utilization of ritual healing practices (Osella \& Osella, 2000). I present the case of Muhammad Mashoor Thangal not because he is representative of all thangal healers, but because he is an example of how an increasing number of ritual healers in Kerala comprehend and situate their practices in a scientific, psychological framework. This is especially relevant in the context of Kerala, where psychology has found its way to the masses through health magazines, newspaper columns, and TV programs.

After presenting the ethnographic evidence of how Muhammad psychologises ritual healing ${ }^{2}$ practice, I ask whether this lack of doctrinal purity ultimately leads to theoretical inconsistency. In answering this question I criticise, in line with recent ethnographic writing (Langwick, 2011; Naraindas, Quack, \& Sax, in press; Sax \& Bhaskar, in press), the dichotomy of science and religion and argue that it is pragmatic realism, rather than doctrinal purity, that characterises a successful ritual healer like Muhammad Mashoor Thangal.

\section{Methods}

The data on which this article is based were collected during a total of 14 months of ethnographic fieldwork in the Malappuram, Kozhikode, and Ernakulam districts in Kerala, South India, between 2009 and 2013. This article is part of a larger project exploring the processes of appropriation of the biopsychiatric notion of depression and its treatment within formal and informal mental health care in Kerala. In order to analyse the psychologisation processes occurring within thangals' ritual healing, I primarily draw upon interviews with Muhammad Mashoor Thangal and participant observation during his patient consultations and treatment. These data are complemented by interviews with other thangals in the primarily Muslim Malappuram and Kozhikode districts, patients and clients in other institutions, biomedical and Ayurvedic psychiatrists and psychologists, and university historians. Some interviews were conducted in English, others were conducted 
in Malayalam. The latter were translated into English with the help of my research assistant, a lower caste Hindu in his forties living in a Muslim neighbourhood in the Kozhikode district. He had an academic background in economics and English literature and a strong interest in psychology. The patient consultations were all conducted in Malayalam, and were recorded for subsequent translation and transcription with the agreement of the patients.

Interview and consultation transcripts were analysed using grounded theory (Bernard, 2011; Strauss \& Corbin, 1990). The process of the thangal's translation of religious terms into psychological ones, which I refer to as psychologisation, became clear after analysing our interviews with Muhammad. Both before and after his patient consultations, Muhammad would explain the strategies that he employed using terms like "third enemies," "autosuggestions," and "proxy revenge." These terms appeared repeatedly as analytic categories in our transcriptions. In order to delineate both the content of his explanation and the process by which he taught us, I begin by presenting vignettes of two consultations that we observed and the postconsultation discussions with Muhammad. I then analyse his techniques more generally and their theoretical implications for research on religious healing. 4

This study was conducted in accordance with the ethical guidelines of the German Research Foundation. Muhammad Mashoor Thangal consented to the study and was explicitly interested in a publication about his practices. He introduced my research assistant and me to his patients and informed them about the purpose of the study. The patients verbally gave their consent to participate and to using their cases in anonymous form.

\section{Thangals in Malabar}

Malabar is a region in Northern Kerala lying between the Western Ghats and the Arabian Sea. Islam is the most common religion, especially in the districts of Kozhikode and Malappuram. Muslims in Kerala differ from North Indian Muslims mainly by the strong Arabic influence in the former. Islam in Malabar spread earlier than in the North through trading relationships beginning in the 7 th century and, later, through travelling Hadrami saints (Osella \& Osella, 2008). The influence of Arabian culture and language continues today through the migration of Malayalam-speaking Muslims seeking work in the Gulf region, a trend that began in the 1970s. ${ }^{5}$ Mappilas are the largest Muslim community in Malabar, settled mainly in the inner Malabar area (Osella \& Osella, 2008). Mappilas are patrilineal and were (until the 1970s Gulf migration) largely agricultural, poor and, according to Kerala standards, uneducated (Osella \& Osella 2007, 2008; see also Dale, 1997; Miller, 1992; Panikkar, 1989).

Thangals ${ }^{6}$ are an endogamous community of Yemeni descent who began to arrive in Kerala in the mid-18th century as ulamas (Islamic scholars) and merchants. The approximately 30 thangal families in Kerala directly trace their origin to the Prophet Muhammad and have written family pedigrees detailing 
each and every descendent (Dale, 1997; Sathar, 1999). Thangal families consider themselves to be the highest "caste" of Muslims in Kerala. Due to their claimed genealogy, thangals are attributed a sacrosanct status and a unique spiritual power (Sathar, 1999) especially among Sunni Muslims, although certainly not all thangals work as healers. "They believe they get cured by us, so they come," as one thangal expressed it. Muhammad Mashoor Thangal emphasised that Sunnis believe in thangals" "sixth sense." He himself, like all other thangals with whom we spoke, neither explicitly claimed nor denied this spiritual power but rather considered it as a possibility. He often switched between a modern scientific and an antimodernist discourse. One of the first things he told us when we met him was that this "sixth sense" is a topic for further research:

We used to say that thangal families have a different gene. That is why we always keep our genome pure by marrying within our family. We are concerned about the purity of our genes. We have a typical personality, a psychological disposition, and a kind of sixth sense. That is what we believe and that is what our clients believe. But the possibility of a sixth sense is a researchable subject. ${ }^{7}$

Invoking an antimodernist and antieducational discourse, he further argued that modern education negatively impacts this presumed sixth sense, which requires extrasensory perception as a diagnostic tool (see Nichter, 2008). He contended that, in contrast to thangal healers, "present day doctors have no sense. They do everything with the help of computers, scans, x-ray, etc. Earlier, doctors diagnosed and treated disease without all of those."

People approach thangals for various problems. According to Muhammad and all thangal healers with whom we spoke, what distinguishes their approach from other medical and religious practitioners is that patients expect thangals to help with disparate aspects of a complex problem at once. They expect a "magic cure" for their mental ill health along with their financial, familial, professional, psychological, or sexual problems, and the thangal intervenes in all areas simultaneously. This is what Muhammad, drawing on alternative critiques of biomedicine, referred to as holism:

No other person could help them in this holistic way. Others are only specialists for distinct realms; nobody is treating all problems at once apart from thangals. All of these problems can be expressed to a thangal. Nowhere else can they express maybe even one of these problems. Here all problems can be expressed together.

Because thangals treat various kinds of problems, going to a thangal is not as stigmatised as seeking care in a biopsychiatric hospital or clinic. For most patients, thangals' religiously sanctioned advice is easier to follow: "If a psychologist gives advice, the people will take $70 \%$. If we say it, the people will take $90 \%$," explained Muhammad. It was striking to see that many women, encouraged by their husbands, did not hesitate to confide even very intimate problems to a thangal. 
When discussing the type of Muslim people who seek the help of thangal healers, a historian working as a teacher in a Muslim college said: "Uneducated people visit thangals during the day. Educated people go at night." This quote speaks to the idea that not only Sunnis but even those Muslims who identify as Mujahid (post-1950s Islamic reformers and proponents of rationality, science, education, and progress) and publicly criticise the thangals' treatments as superstitious, financially exploitative, and even dangerous, will secretly visit thangals in times of serious personal crises. It shows, as Sax (2009, p. 233) has expressed it, "that the overt rejection of ritual healing was not so much a statement of disbelief in its efficacy as it was an assertion of one's social position: modern, educated, and scientific." In order to avoid jeopardising this position, "educated people go at night." When I asked Muhammad Mashoor Thangal about this statement, he elaborated: "That is correct. But nowadays, educated people have also started coming during the day. They will come for other reasons, with a friend or someone else." He points towards the growing acceptance, rather than decline, of ritual practices related to distress and crises, and how it parallels the increasing importance placed on ritual treatment for mental illness and other personal gains in Kerala.

\section{Muhammad Mashoor Thangal}

In this essay I focus on one particular thangal, Muhammad, who engages in modernist Mujahid discourse incorporating science and rationality and in antimodernist discourse. Muhammad is a thangal healer in his forties who belongs to the lineage of Ba'ahood on his father's side. The written history of Muhammad's patrilineal ancestors dates to the 12th century in Hadramaut, Yemen. Like all thangal families, the Ba'ahood claim direct descent from the Prophet's family. From the beginning, Muhammad introduced himself as a traditional thangal with his own idiosyncratic approach, making clear that part of his efficacy refers to his familiarity with and incorporation of psychological methods. Muhammad's small "clinic," as he calls it, is located in a rural area in the Kozhikode district, in a house where he lives with his wife, children, mother, and brother's family. Here he treats between 10 and 20 patients per day. Muhammad learnt his practice from his grandfather and father ${ }^{8}$ and was educated up to $12 \mathrm{fth}$ standard. Afterwards, he earned a degree in counselling from a short-term course offered, interestingly enough, by Catholic nuns. In this course, he was taught the basic biopsychiatric classifications, drugs, and therapeutic techniques. According to him, becoming a thangal depends both on an individual's wish and inclination and on certain signs that he (or rarely she) displays. No one, he stressed, is forced against his will and his disposition to become a healer.

It mainly depends on our interest. Not only that, we also consider our sixth sense. During the developmental changes of a boy, we notice these signs in him. Suppose the boy has this sense; we will decide whether he is apt to learn [to be a healer]. 
Although there is no special age for initiation into the art of healing, most of the boys who later work as healers begin showing interest and displaying signs during the onset of puberty. Muhammad himself began developing this interest at the age of 12. During this time, he collected philosophical and religious quotes from newspapers and discussed them with his father and grandfather. His stoic nature and concern for others were interpreted by his relatives as signs of a healer. He slowly became initiated into healing techniques by his grandfather and father while simultaneously studying psychology textbooks.

Muhammad has his own way of practicing and understanding religious healing that I term "psychologisation." While he uses techniques based on the Qur'an and pre-Islamic mantras and yantras that are shared by most other thangals, he reframed these techniques in psychological terms.

MMT: Basically I am a thangal. In a practical sense I use thangals' methods but I read our traditional books and compare them with psychology and develop my theory. This is the advantage of our traditional prayers and our traditional method. I am comparing.

CL: So you combine traditional knowledge and modern psychological knowledge and create your own way of treatment?

MMT: Create, no. I confirm the traditional way and use some advantages.

Thus, the modern science of psychology confirms the "traditional" knowledge, which is again elevated to a scientific level. One of Muhammad's cousins relates Muhammad's psychological reframing of the healing techniques of thangals to his scientific temper, characterised by his early interest in science and psychology:

There are very few thangals who understand it in the way Muhammad will understand it. You may have understood it by this time. We've been friends from a very early age. We grew up together, we learned together, we lived together. I started reading from his book collection. We used to read psychology; we used to have psychological magazines. So, in fact, it's [Muhammad] who put that seed of logic into my brain. That actually triggered my quest for knowledge. He still has quite a lot of interest, so he reads different kinds of subjects. He studied a variety of subjects, which gave him the kind of perspective that is helping him as a thangal healer or practitioner.

Through discussion with his gurus, family members and friends-but not his patients-Muhammad has been trying to reconcile what he calls "traditional" thangals' practices and modern psychological theories. Thus, the term psychologisation stems from his own hybrid way of making sense of his profession, which is nevertheless relevant for other thangals who struggle to reconcile these diverse epistemologies. 


\section{Trick or treat? Third enemies, proxy revenge, and autosuggestions}

In the following pages, I will present a selection of Muhammad's psychological techniques and his model of efficacy, as outlined by him. It is important to state that the discourses expressed by Muhammad and his patients are characterised by the hegemony of the biopsychiatric and psychological discourses of mental illness over religious ones. The following two vignettes will elaborate on Muhammad's practice.

\section{Vignette I}

Hamid, in his early thirties, sought help from Muhammad because of problems with his wife Fatimah, to whom he had been married for 5 years. According to Hamid, Fatimah had been compelled to marry him by her parents even though she herself had wanted to marry another man. Although Hamid's financial position was much lower than hers, she finally agreed to marry him. After moving into his house, however, she was unable to "adjust" to her husband's socioeconomic situation and "wanted to live a modern life." The situation eroded after Hamid left to work in the Gulf 3 months after their wedding and left his wife in Kerala with his family. Soon after, she returned to her parents' home and stayed there instead of with her in-laws, which traditionally would have been her duty. Eventually, she returned to Hamid's house. At this point, Hamid learnt that Fatimah had had sexual relations with her brother during the time he was away. She had become pregnant but aborted the baby, fearing that the birth might reveal the truth. Now the situation was reversed: Hamid did not want his wife in his house anymore, while his own parents did not understand and wanted Fatimah to remain. Hamid was now deeply conflicted, as he could neither accept his wife nor disobey his parents. As with most of Muhammad's patients, Hamid himself gave a clue about where to start his religious treatment. Before marrying Fatimah, he was supposed to marry another girl. However, after learning that the girl's father had had an illicit sexual relationship, Hamid broke off the engagement. He confided to Muhammad:

I think I have that girl's curse on me. That girl didn't get married for the next year and a half. She didn't marry even after I got married. I think it is her tears that caused all of these troubles in my family.

The thangal confirmed Hamid's own explanation by saying "Of course, that is it," thereby transferring the fault from his wife towards a "third enemy." Thus, he provided a sacrosanct validation of Hamid's own theory. Hamid planned to take his wife for counselling, and Muhammad referred them to a Catholic nun. He later explained that Hamid might have a paranoid delusion of his wife's affair with her brother but is not ready to undergo treatment himself: 
He himself says that all this could be the result of a curse that was laid on him by a girl who wished to marry him and whom he ditched. I asked questions again and again until he told me about that curse. Now I will focus only on that and I will make him believe that the real reason for his present condition and for all the troubles with his wife, is the curse of that disappointed girl. By this, I will solve this issue and save his wife. I have accepted everything that he has said and through that I have earned his trust. Although he wants to take his wife to a counsellor, the counselling will ultimately be for him.

The unfaithful wife would be the natural "first enemy" of her betrayed husband, causing his troubles. But Muhammad's deflection of responsibility onto a "third enemy" (the girl who cursed Hamid) is therapeutic for everyone involved.

\section{Vignette 2}

Harsha, a woman in her forties and mother of three children who had married into a rich Muslim family, approached Muhammad because of tension over the sale of a property. She began her narrative by saying: "I cry every day thinking about my life. It has been like this for the last 23 years." It was not the first time that Harsha came to him; she had been seeking his help over many years for various problems. This time she told him about her extramarital affairs, which she had not revealed earlier. Muhammad explained that because of her guilty conscience and regret, she attributed the difficulty with selling their property to these past illicit sexual relationships.

These affairs began at the age of 13 when she entered a new class and was introduced to a boy who subsequently fell in love with her. However, while still in seventh standard, she married another man. Even though she had stopped seeing that boy, she began a series of sexual relationships while her husband was in the Gulf working; twice she even became pregnant and sought abortions. A few years ago, a woman who approached their house to ask for money told her that in the past somebody had tried to destroy her life and stunt her prosperity by giving vashyam (sweets given to seduce a woman) when she was in seventh standard, a suspicion that has since been creeping into her mind. Muhammad confirmed this suspicion that all of her problems, including her affairs and the difficulties with selling their property, had been caused by that vashyam, which was probably given to her by the boy who had first fallen in love with her. He consoled her saying that he could do something to counter all these influences. After she left, the thangal explained:

Her problem is that of regret over her extramarital affairs. She says that somebody had given her some sweets when she was in seventh standard and that all her problems occurred because of that. It is an escape mechanism. I will work on it. I will focus on the sweets that she talked about. "Anybody would have gone astray if such sweets had 
been given." That is what I will convince her of. In this way I will neutralise her regret. ... If I deny it, she will deny me. So I will solve this issue using her own point of view.

As hinted at in the vignettes above, one of the main techniques Muhammad uses is what he calls "creating a third enemy." Muhammad offered another example of a wife being depressed ${ }^{9}$ because her husband had an extramarital affair:

They will go to a psychologist, psychiatrist, to many people. Finally they will come to [a thangal]. We will tell him that it is not [his fault]. Satan has affected him. We create a third enemy. Normally [the husband would be] the first enemy. We create the third enemy. That is the religious way or traditional way; that is our technical way. If they are believers, we can cure it $100 \%$.

Thus, by creating a third enemy, the thangal diverts both the responsibility for the husband's infidelity and the anger of his wife away from the husband towards Satan or "a negative energy." His Muslim patients, as well as many other patients in Kerala and elsewhere in South Asia, are more ready to ascribe the source of abnormal and undesirable behaviour and mental illness to external causes such as malevolent people and other agents, sorcery, evil spirits, or the stars than to internal psychological or psychodynamic states. In the two vignettes above, the thangal created, or rather confirmed, the third enemies his patients had mentioned in their narratives. In Hamid's case it was the girl he refused to marry who had laid a curse upon him, whereas in Harsha's case it was somebody who had given her magically poisoned food while she was in seventh standard.

A concept similar to the "third enemy" is what Muhammad calls "proxy revenge" and what my research assistant later paraphrased as "proxy expression" or "safe expression of anger." According to the thangal, some ayats in the Qur'an are used by other thangals (but not by him) to provoke calamities, adversities, and other negative effects in the victims. The use of different forms of "magical violence" is indeed quite common in Kerala today (see Tarabout, 2003). Without dwelling on the question of whether or not these actions can have a real effect or not, Muhammad elaborated his understanding of the efficacy of using these ayats. In his opinion, if a person holds a grudge against somebody else, he or she might be tempted to wreak revenge on the enemy and seek a thangal's assistance. According to his principle of always supporting and confirming his clients, Muhammad will agree and prepare a thakkidu reinforced with pepper seeds ${ }^{10}$ to be buried in the enemy's compound or to be burned with mustard seeds in the kitchen fire while chanting the presumably malevolent ayats. These actions will have a double effect: First, the person will not express his or her anger in a direct way in the form of an assault, which would provoke future problems. Rather, he or she will express it through indirect "proxy revenge." Second, the assumption that proper revenge has been taken will pacify the person's mind. In this way, Muhammad reinterprets "magical violence" in the secular term of "proxy revenge" in which the clients' vengeful feelings are assuaged by performing the spell. 
Muhammad's notion of "proxy revenge" is in striking similarity to what Obeyesekere (1975) has written about sorcery in Sri Lanka. Obeyesekere argues that ritual cursing is the psychological equivalent of "attempted homicide" and that if the police recorded it, they would have a more accurate view of how many homicides are really attempted. Sorcery, Obeyesekere, writing from a psychoanalytical point of view, argues "provides culturally constituted mechanisms for the canalization of the aggressive impulses of individuals" (1975, p. 11) and is thus a means by which premeditated murder is channeled away from physical violence into sorcery. If expressed through sorcery, Obeyesekere says, the aggression need not be expressed through overt practice of planned violence.

Another example of the psychological reframing of religious assumptions is the case of "pseudoseizures" and "hysteria." Defined in biomedicine as episodes of behaviour that resemble epileptic seizures, but in which electroencephalography (EEG) patterns characteristic of epilepsy are not present (Yeh, 1996); pseudoseizures (or nonepileptic seizures) are much more frequent in India than in Western countries, according to many biopsychiatrists I spoke to in Kerala. In psychiatry, the etiology of pseudoseizures is usually related to stress, to a certain kind of personality, to past experiences of sexual abuse, or to unconscious and conscious gains drawn from the seizures. Pseudoseizures have been related to the anthropological literature on trance and possession states (Yeh, 1996). Many Muslims in Kerala who approach a thangal for help, and several thangals themselves when faced with the problem of seizures, assume the influence of $b \bar{a} d h a$ (evil spirits) or of Shaitan (Satan) and thereby frame pseudoseizures within the idiom of possession and evil spirits. Muhammad confirms their explanation and treats them with different techniques that his patients understand as shaitan orippikkal (removing Satan), such as singing and blowing ayats on the head of the victim. However, Muhammad himself offered a psychological explanation of this phenomenon. According to him, pseudoseizures are cases of hysteria that should be treated by what he calls "Pavlov's method," by which he means the transforming or de-conditioning of conditioned behaviour or, in other words, the negative reinforcement of possession behaviour, replacing years of positive reinforcement by family members. He maintained that his own treatment methods for pseudoseizures are superior to biopsychiatric or psychological treatment and act much more quickly:

If a woman collapses with hysteria, she will cry, make a lot of noise, and create many problems. Her family, normally a psychologist, ${ }^{11}$ and the whole society will help her, put her to bed and give her water. If another problem comes up she will repeat [the seizures again and again]. That is hysteria. Everyone gives medications and uses calming methods [to treat this]. If that type of woman comes to me I will first tell her family that an evil, satanic energy is affecting her. Then, the second time, I will take the, you know, Pavlov's theory, the Russian psychologist, I will take medicine that is irritating to her eyes, her nose, and her mouth. It has a bad taste, a bad smell - it is very difficult - in order to use it as a holy device. I will pray and use this irritating medicine on her. For some cases, I will take a rod and beat her, not 
in a harmful manner, but for treatment. Technically we are beating them. ${ }^{12}$ Some believe in satanic energy, but I know Pavlov's theory. "I have some tension, I want some help? I collapse." The society always helps her. But if she comes to me, I will treat her and in front of her I will tell her parents that the evil energy will be gone now. If the energy comes again I will ask them to come see me again. Normally my experience is that $95 \%$ never repeat the seizures. For 10 years she has been repeating these symptoms, collapsing, getting help, collapsing again, getting help again. If she comes to me and collapses again, she gets beaten, so she will never repeat it again. One session is enough. ... If their unconscious mind knows it is painful, ${ }^{11}$ Pavlov's theory, then they will stop that behaviour.

While most other ritual specialists who use beatings in their treatment emphasise that they do not beat the patient but rather the satanic energy or evil spirit acting inside of the patient, Muhammad clarifies that the beating directly targets the "hysteric" patient by punishing her for her behaviour. In this way, he reverses the conditioning of pseudoseizures, which he understands as attention-seeking behaviour, and according to him cures most cases of hysteria.

Muhammad further uses a special kind of astrological and numerological calculation called the "Arabic horoscope" for diagnostic and therapeutic purposes. As with the other techniques mentioned above, he did not deny nor affirm its truth content; instead, he presented his calculations mainly as a tool for producing what my research assistant called "therapeutic fabricated facts." These fabricated facts might include third enemies, bad deeds performed by somebody else, problems related to the architecture of the house $(v \bar{a} s t u)^{13}$ that cause mental problems (such as the incorrect location of the toilet), or simply a bad time in cosmological constellations. The latter idea serves multiple purposes; for example, he uses it to create a structured daily schedule for what could be termed "cosmologically based cognitive-behavioural therapy":

In some conditions like depression we say that your star is now very bad, but your time is good in the morning from 5 a.m. until noon. During this time, if you work, the result will be good. But, in the afternoon, your time is not good. Your work will not be effective. Through this we reduce their total 24 hours into 6 hours, their activity up to 6 hours. They will accept that and in the early morning wake up and go to work.

Doing namaz (daily prayers) five times a day can be another way of structuring the day and involving patients in activities. Repeating certain ayats or surats regularly is effective as an "autosuggestion method," as he calls it. In the case of depression, he will prepare a thakkidu, give it to the patient and ask her to bury it somewhere in her compound. Thakkidus and elassus are the most frequent and well-known prophylactic and therapeutic devices that thangals use. These are Qur'anic verses (ayats and surats), written either on a piece of paper (narukku) or on copper, which are then rolled and inserted into a small round silver or golden case. This is paid for by the patients ${ }^{14}$ and worn around the neck, waist, or upper arm. 
Usually, the patients are not told what is written in the paper or copper. There are many ayats and surats, and each is used for specific afflictions. Some are for specific problems and others for general mental health and peace of mind. Muhammad explained that elassus are used for individual problems. If the whole family is afflicted, a thakkidu is prepared in which a paper or copper piece inscribed with ayats, surats and/or yantras (diagrams) is inserted into a bottle and either buried within the compound or hung outside the house. For chronic worrying thoughts in depression, he will tell the patient, "Your mind is wandering to places where it should not go. The fixing of the thakkidu will also fix your mind and prevent it from wandering around."

Asking a restless and distressed patient to pray a special Arabic mantra every day or blow it into water and drink it is also a part of Muhammad's "wait-and-see method." He will convince the patient that it is not a good time to make a decision, and that she should pray Arabic mantras for a certain period of time. Justifying his reasoning using astrological calculations, he prevents ill-reflected, spontaneous decision-making. The creation of therapeutically fabricated facts occurs in a context of trust and confidence. In the thangal's vision, it is not a lie or trick ${ }^{15}$ in a negative or dishonest sense, but rather a therapeutic tool. The thangal must be empathetic and understanding towards the patients' thought patterns in order to select the right ideas around which to build a treatment.

Finally, Muhammad often uses Ayurvedic, Unani, or allopathic medicines as part of his religious treatment, either to convince unwilling patients of their necessity or to ritually empower them and thereby reinforce their efficacy. For example, he informs some of his patients that they have satanic energy in their bodies that can be counteracted by psychopharmaceuticals. He is not the only practitioner who uses Ayurvedic, Unani, or allopathic drugs for mental disorders as a means to combat Satan, sorcery, or other supernatural influences; indeed, I observed Muslim psychologists use these explanations for similar purposes.

\section{"Whatever foolish thing you say, we thangals will support you": Psychologisation, ontological openness and pragmatic realism}

Muhammad Mashoor Thangal explained that the crucial feature that distinguishes his treatment from biopsychiatrists' or psychologists' is the fact that he understands and confirms his patients' subjective experiences and explanations, and engages their framing of the problem when it comes to healing:

The people around the world consider mantrachikitsa [treatment using Qur'anic verses called mantras] as the most superstitious thing. But in my opinion, an experienced person who really cares for the people around him is almost as capable as any Ayurvedic or allopathic doctor to treat [mental illness]. It is a type of pastoral counselling. We are specifically studying individuals to solve their problems. To an outsider, it would appear to be sorcery or fraud or something like that. But there is the 
matter of effective communication between the patient and [the healer]... . Now, I can understand them and come down to their level and talk to them. Suppose you are a psychiatric patient and you believe that evil spirits are with you. If you approach a psychiatrist, they will diagnose you as insane. But if you come to me, I will agree with you. I will believe you and as a result you will trust me, too. And we will move forward together. But a psychiatrist will never do that. His actions will always be against you. Whatever foolish thing you say, we [thangals] will support you.

Muhammad positions himself within a rationalist discourse of modernity and science. He anticipates the modernist critique of mantrikachikitsa as "most superstitious" and counters it by reframing his healing as "pastoral counselling." By using this term, Muhammad engages a North American Christian approach dating to the first half of the 20th century and widely used in the Christian context of Kerala today. Pastoral counselling is a form of counselling that is usually practiced by Christian priests and integrates psychological and religious methods and theories in order to address what could be called psycho-spiritual issues (Augsburger, 1986). It integrates religion and science, faith and rationality. If Muhammad-who has studied the basic techniques of psychological counselling from Christian missionary nuns - transfers this Christian term and technique to his own practice, he counters rationalists' critique of mantrikacikitsa as superstitious by denoting it as both "traditional" and "modern," religious and scientific.

When he says that thangals study individuals to solve their problems, he means not only that he tries to understand the nexus of personal, social, and spiritual linkages but also that he studies his patients' explanatory models. He contrasts this technique of understanding, and the resultant relationship between him and his patients, with biopsychiatric encounters in which, according to Muhammad, doctors impose a diagnostic label on the subjective experience of the patient.

Muhammad's approach begins from the subjectivity and explanations that he elicits from his patients. Although in Kerala there has not been a discourse of antipsychiatry as such, his positioning vis-à-vis biopsychiatrists echoes the antipsychiatric critique of classifying people with psychotic ideas and abnormal behaviour as mad instead of trying to understand them within their own frames of reference. So, rather than practicing "witchcraft" - a practice characterised from a rationalist standpoint as the lack of relationship between an agent and an effect- - he understands his practice as "effective communication," again a fashionable term borrowed from popular psychology. Muhammad uses this term in the sense that he "comes down to their level," "agrees with them" on their experiences and assumptions, whatever they are, and treats them accordingly. Going one step further, he also acknowledges the possibility that some things biopsychiatrists might consider psychotic are in fact real "in some rare exceptions." So, if Muhammad takes the sensory experiences, subjectivities, and explanatory maps ${ }^{16}$ of his patients seriously, it is first and foremost for therapeutic purposes but also, in other cases, out of ontological deliberations. Muhammad is never unambiguous about ontologies, meaning the question of what really exists and what does not. Although he 
translates most causative factors and therapeutic measures into psychological language, there is always a "rest," a possibility that he neither denies nor explicitly defends: the existence of sorcery, spirits, witchcraft, and so on. He never explicitly denied the possibility of the ontological existence of malevolent forces and the option to effectively address them by what he calls the "traditional methods of thangals." The difference between his beliefs and those of the majority of his patients is that, according to him, a real supernatural influence is very rare and not as frequent as they assume.

Kleinman (1980) and others have argued that the shared explanatory models of "folk healers" and their patients are one of the things that the efficacy of ritual healers rests upon. What we learn from people like Muhammad is that he not only shares but also purposefully elicits the explanatory models of his patients in order to engage them and to build his treatment strategy. This is what he calls "effective communication," and this is what explains the efficacy of his healing.

In Kerala, psychology permeates almost every area of life. Health magazines, columns in newspapers, and TV programs deal with psychological issues; an increasing number of clinical psychologists are entering the field of mental health care, most schools employ a psychologist, camps for adolescents deal with psychological issues, and counselling centres are mushrooming everywhere. Although not as powerful as biopsychiatry, psychology is conceived of as a science related to "modernity" and "the West." Halliburton (2005) has described the decline of spirit possession and the rise of psychological idioms such as "tension" and "depression" as idioms of distress in Kerala. He interprets the spread of psychological idioms as signalling an "erosion of context and the ascendance of universal categories" (Halliburton, 2005, p. 111) that are important features of "modernity" (Halliburton, 2005, following Ramanujan, 1989).

Tarabout (1999) used the term "psychologisation" to describe how many ritual or religious healers in Kerala appropriate psychology in order to express the process and the efficacy of their healing. According to him, psychology has become the dominant reference point for religious healing, "not only because of its intrinsic virtues but also because it is associated with a technologically (and politically) dominant West" (Tarabout, 1999, p. 149). The process of psychologisation is thus marked by an asymmetry of the scientific psychological idiom and the devalued religious idiom. Framing ritual healing practices in a psychological idiom helps to legitimize them as modern and scientific. Tarabout (1999, p. 137) describes two kinds of psychologisation. In the first case, religious healers appropriate psychology by merely "coating" or "superimposing" both the role of a psychotherapist and psychological terminology on religious notions without linking the two ontological frames of reference at all. In the second, healers attempt to relate their own therapeutic tradition to the perceived logic of psychology, which leads to interrogations and dialogue. According to Tarabout, in both cases psychology and religion are only nominally blended, not ontologically; the ontologies remain logically unconnected. I argue that this is also true for the case of Muhammad where religious ontologies are largely translated into psychological ones. He leaves an 
ontological space for religious explanations but does not blend psychology and religion. When Muhammad Mashoor Thangal uses a psychological idiom to explain his therapeutic techniques and thereby "translates" religion into science, blurring the boundaries between nonscience and science, tradition and modernity (Latour, 1991), he replaces the ontology of human and nonhuman malevolent agents by a psychological idiom. Yet, his therapeutic practice opens the space for multiple coexisting ontologies that are "created through therapeutic practice" (Langwick, 2011, p. 12): the real existence of sorcery, spirits, and Satan and the ability of his treatment to effectively address these entities through what Muhammad calls the "traditional methods of thangals." In these cases, ritual healing might work for reasons other than psychological ones. Thus, the encounter between science (psychology) and religion leaves Muhammad with an open space to a multiplicity of coexisting and contested ontologies for his therapeutic interventions, which he nevertheless prefers to explain in psychological terms. $\mathrm{He}$ believes that this psychological framing renders his treatment modern and scientific on the one hand and superior to psychological and biopsychiatric treatments on the other. Psychology confirms the efficacy of the treatment modalities that thangals have always used.

Does the evidence provided by Muhammad Mashoor Thangal suggest theoretical chaos and inconsistency? Is he a modern or a traditional healer? Is he a psychotherapist or a ritual healer? Does his treatment address malevolent agents or psychological processes? The case of Muhammad shows that the modernist dualism between science and religion that underlies these questions cannot be sustained in practice. Rather, the dualism is part of modernist "purification" (Latour, 1991) that aims at, but never succeeds in, purifying science from anything social, cultural, or religious. Along with other binary oppositions such as modern/traditional and Western/Eastern, the science/religion dualism is an ideology rather than a reality, which is created and maintained by powerful institutions and practices (Langwick, 2011; Naraindas et al., in press; Sax \& Bhaskar, in press).

Muhammad is extremely pragmatic and not overly concerned with doctrinal and theoretical purity. The aim of his treatment is to do all he can to help his patients. Like most other thangals, he uses a variety of techniques based on the Qur'an and pre-Islamic mantras and yantras. He also prescribes Unani and Ayurvedic medicines and sometimes biopsychiatric psychopharmaceuticals that he ritually charges by reciting ayats and surats over them. Like most other thangals, he listens empathetically to his clients and tries to find solutions to their problems. And like most other thangals, he addresses his patients' own explanations and framings of their problems, a method he calls "effective communication." However, unlike other thangals, he reframes these concepts and the effects of his treatment in a psychological idiom. His treatment "methods" that he reinterprets as "psychological," such as "creating a third enemy," "proxy revenge," "Pavlov's method," and "autosuggestion," don't (primarily) address malevolent agents but aim instead at manipulating the psychological processes of his clients. Yet, even though as a rationalist, Sufi, and thangal (with a "sixth sense"), Muhammad understands the efficacy of his 
treatment mainly in psychological terms, he does not exclude the possibility that his "tricks" might nevertheless also manipulate nonhuman malevolent agents. His pragmatic realism and his ontological openness prevent him from the ontological struggles of the famous Kwakiutl shaman Quesalid, an informant of the anthropologist Franz Boas at the end of the 19th century. Quesalid started learning about shamanism in order to reveal its fraudulences and was confirmed in his worst suspicions, but ended up being a highly successful healer anyway (Lévi-Strauss, 1963). Until the end, his ontological struggles about the efficacy of his treatment and the existence of the illness-causing agents remain unresolved. Muhammad engages the explanatory model of his clients with his practice, but like Quesalid he does not share their explanations himself. Instead, he seeks psychological mechanisms to account for the healing. But unlike Quesalid, Muhammad does not completely reject the possibility of the malevolent influence of Satan, sorcery, and curses on his clients and subsequently of the religious efficacy of treatment.

\section{Conclusion}

I have used the case of one thangal healer as an illustration of an increasing number of ritual healers in Kerala who engage with the modern discourse of psychology in their practices (Tarabout, 1999). The psychologisation of ritual healing is, I maintain, part of the increasing rationalisation and scientification of therapeutic practices in Kerala and beyond, whereby traditional healers themselves negotiate science, modernity, and religion and position their practice within these contested fields. This process is an important counterpoint to the common practice by local and national authorities in India of ignoring or even sometimes forbidding ritual healing on the basis that it is not in concordance with science (Sax \& Bhaskar, in press). It shows that, in the wake of modernity, vernacular healing knowledge and practices have not simply been washed away by a "tide of modernization," which in the case of mental distress refers to the theory and practice of biopsychiatry and Western psychology. Instead, ritual healers play an active role in shaping and transforming the process of therapeutic modernisation with the result that specific local forms of therapeutic modernity arise. As Tarabout (1999) has also shown, ritual healers themselves reformulate and translate religious etiologies and ideas of effectiveness into the language of psychology without completely giving up the ontological possibility of the formers' existence, as in the case of Muhammad. Thus, ritual healers bear witness to an "alternative modernity" (Gaonkar, 2001) that is regionally (Sivaramakrishnan \& Agrawal, 2003) or locally (Gupta, 1998; Halliburton, 2005) produced and experienced. Further, they show that a therapeutic modernity as a specific form of local modernity is a contested terrain and "a zone of cultural debate" (Appadurai \& Breckenridge, 1988, p. 6).

While for modern "purifiers" (Latour, 1991), ritual healing is seen as "being directly antithetical to modern scientific practice" (Sax \& Bhaskar, in press), ritual healers such as Muhammad Mashoor Thangal blur these boundaries by translating 
religious framings of their practices into a psychological idiom without completely giving up the ontological possibility of their religious effectiveness. The psychological "tricks" he uses with his patients along with the ease with which he translates the religious idiom into the psychological suggest that Muhammad, like most successful healers, is extremely pragmatic and not overly concerned with theoretical purity. Therefore, I argue that in order to understand the healing practice of "ritual" or "folk healers," we should not look for doctrinal purity so much as for pragmatic realism. As recent writing attests, pragmatism characterises not only the approach of successful healers, but above all the help-seeking behaviour of patients in India (Quack, 2013).

\section{Funding}

This research was funded by the German Research Foundation (DFG) from 2009 to 2011 and from 2012 to 2015.

\section{Acknowledgements}

I am grateful to the three anonymous reviewers of Transcultural Psychiatry and to Karen Dyer for their helpful critical remarks and inspiring suggestions on an earlier version of this paper. I also wish to thank my research assistant Babu Appat for his translations and explanations and Muhammad Mashoor Thangal for his teachings and patience.

\section{Notes}

1. The correct transliteration would be tainigal, but for reasons both of better readability and popularity of the transliteration thangal, I use it too.

2. For a critical discussion of the notion "ritual healing," see Sax (2009, p. 238).

3. In this paper, I focus on a single case. Within ethnographic writing, this method has been used by several authors with Crapanzano's Tuhami: Portrait of a Moroccan (1980) and Shostak's Nisa: The Life and Words of a !Kung Woman (1981) being famous examples.

4. This study was conducted in accordance with the ethical guidelines of the German Research Foundation. Muhammad Mashoor Thangal consented to the study and was explicitly interested in a publication about his practices. He introduced my research assistant and me to his patients and informed them about the purpose of the study. The patients verbally gave their consent to participate and to using their cases in anonymous form.

5. Most Muslim and many Hindu and Christian men in Kerala work in the United Arabian Emirates, Oman, Kuwait or Saudi Arabia for a certain period in their lives. For an ethnography of Gulf migration, see Osella and Osella (2007).

6. Thangal is a Malayalam honorific title that the sayyids or sāda received in Kerala.

7. Muhammad's English statements are edited by the author, changing only as much as necessary for understanding.

8. This is one form of the transmission of healing knowledge within thangal families. In other cases, thangal healers also learn from a guru (teacher) outside their family.

9. The English term "depressed" is used in Kerala in different ways. Here, Muhammad meant sad, disappointed and angry, with occasional violent behaviour. 
10. Burning pepper seeds can cause irritating physical effects, thereby convincing the person of the magic medicine's malevolent power.

11. Muhammad, like many other lay people in Kerala, used the terms "psychologist" and "psychiatrist" (i.e. biopsychiatrist) interchangeably. Even doctors other than modern psychiatrists sometimes have difficulty differentiating these terms.

12. Because Muhammad never used this technique in our presence, we were never able to verify what the beatings actually entailed or the degree of physical pain they caused.

13. Vāstu shastra is an ancient Indian body of knowledge about sacred and profane architecture and its relationship to the inhabitants (Chakrabarty, 2013), which has experienced a dramatic revival in recent years through promotion in TV shows and newspaper columns. It is used by Hindus, Muslims and Christians. I have met many Hindu and Muslim families in psychiatric hospitals and ritual healing settings who had been advised to reconstruct parts of their house in order to relieve a family member affected by mental distress or illness. In the Malappuram and Kozhikode districts, vāstu shastra is practiced primarily by Muslims. An analysis of how exactly Muslims transform Hindu concepts into a Muslim framework is a topic for future studies.

14. Although Muhammed Mashoor stressed that he lets patients decide how much to pay for treatment, the payment still influences the particular modalities he chooses. On the other hand, he even claimed to give rather than to receive money from some of his patients in order to financially support them. Thus, there is no one-size-fits-all therapy.

15. The term "trick," as in the subtitle, is my term. Muhammad himself never used the term for his techniques although the way he presented them to us suggest this term. With regard to ritual healers' "tricks," see Lévi-Strauss (1963) on the Kwakiutl shaman Quesalid, based on Boas' informant

16. Explanations and subjectivities as a nexus of heterogeneous discourses are characterised much more by incoherence, uncertainties and cracks than coherence and stability. For this reason, Williams and Healy (2001) have criticised the term "explanatory models" as too fixed and have suggested replacing it with the term "explanatory maps" of various eclectic explanations when individuals attempt to interpret their own experiences.

\section{References}

Appadurai, A., \& Breckenridge, C. (1988). Why public culture? Public Culture, 1(1), 5-10. Augsburger, D. W. (1986). Pastoral counseling across cultures. Philadelphia, PA: Westminster Press.

Bernard, H. R. (2011). Research methods in anthropology: Qualitative and quantitative approaches. Walnut Creek, CA: AltaMira Press.

Chakrabarty, V. (2013). Indian architectural theory: Contemporary uses of Vastu Vidya. Richmond, UK: Curzon Press.

Dale, S. F. (1997). The Hadrami diaspora in South-Western India: The role of the Sayyids of the Malabar Coast. In U. Freitag, \& W. Clarence-Smith (Eds.) Hadhrami traders, scholars and statesmen in the Indian Ocean, 1750s-1960s (pp. 175-184). Leiden, the Netherlands: Brill.

Gaonkar, D. P. (Ed.) (2001). Alternative modernities. New York, NY: Duke University Press.

Gupta, A. (1998). Postcolonial developments: Agriculture in the making of modern India. Durham, NC: Duke University Press.

Halliburton, M. (2005). "Just some spirits": The erosion of spirit possession and the rise of "tension" in South India. Medical Anthropology, 24(2), 111-144. 
Kleinman, A. (1980). Patients and healers in the context of culture: An exploration of the borderland between anthropology, medicine, and psychiatry. Berkeley: University of California Press.

Langwick, S. A. (2011). Bodies, politics, and African healing: The matter of maladies in Tanzania. Bloomington: Indiana University Press.

Latour, B. (1991). We have never been modern. Cambridge, MA: Harvard University Press. Lévi-Strauss, C. (1963). Structural anthropology. New York, NY: Basic Books.

Miller, R. E. (1992). Mappila Muslims of Kerala: A study in Islamic trends. Madras, India: Orient Longman.

Naraindas, H., Quack, J., \& Sax, W. S. (in press). Introduction: Entangled epistemes. In H. Naraindas, J. Quack, \& W. S. Sax (Eds.) Asymmetrical conversations: Contestations, circumventions, and the blurring of therapeutic boundaries. New York, NY: Berghahn.

Nichter, M. (2008). Coming to our senses: Appreciating the sensorial in medical anthropology. Transcultural Psychiatry, 45(2), 163-197.

Obeyesekere, G. (1975). Sorcery, premeditated murder and the canalization of aggression in Sri Lanka. Ethnology, 14, 1-23.

Osella, F., \& Osella, C. (2000). Social mobility in Kerala: Modernity and identity in conflict. London, UK: Pluto Press.

Osella, F., \& Osella, C. (2007). "I am Gulf": The production of cosmopolitanism in Kozhikode, Kerala, India. In E. Simpson, \& K. Kresse (Eds.) Struggling with history: Islam and cosmopolitanism in the Western Indian Ocean (pp. 323-356). London, UK: Hurst.

Osella, F., \& Osella, C. (2008). Islamism and social reform in Kerala, South India. Modern Asian Studies, 42(2-3), 317-346.

Panikkar, K. N. (1989). Against the Lord and the State: Religion and peasant uprisings in Malabar 1836-1921. Delhi, India: Oxford University Press.

Quack, J. (2013). "What do I know?" Scholastic fallacies and pragmatic religiosity in mental health seeking behaviour in India. Mental Health, Religion \& Culture, 16(4), 403-418.

Sathar, M. A. (1999). History of Ba 'Alawis of Kerala (Unpublished doctoral thesis). Calicut University, India.

Sax, W. S. (2009). God of justice: Ritual healing and social justice in the central Himalayas. New York, NY: Oxford University Press.

Sax, W. S., \& Bhaskar, H. (in press). A healing practice in Kerala. In H. Naraindas, J. Quack, \& W. S. Sax (Eds.) Asymmetrical conversations: Contestations, circumventions, and the blurring of therapeutic boundaries. New York, NY: Berghahn.

Sivaramakrishnan, K., \& Agrawal, A. (2003). Regional modernities in stories and practices of development. In K. Sivaramakrishnan, \& A. Agrawal (Eds.) Regional modernities: The cultural politics of development in India (pp. 1-61). Stanford, CA: Stanford University Press.

Strauss, A., \& Corbin, J. (1990). Basics of qualitative research: Grounded theory procedures and techniques. Thousand Oaks, CA: Sage.

Tarabout, G. (1999). "Psycho-religious therapy" in Kerala as a form of interaction between local traditions and (perceived) scientific discourse. In M. Carrin (Ed.) Managing distress: Possession and therapeutic cults in South Asia (pp. 133-154). New Delhi, India: Manohar.

Tarabout, G. (2003). Magical violence and non-violence: Witchcraft in Kerala. In D. Vedal, G. Tarabout, \& E. Meyer (Eds.) Violence/non-violence: Some Hindu perspectives (pp. 219-254). New Delhi, India: Manohar. 
Williams, B., \& Healy, D. (2001). Perceptions of illness causation among new referrals to a community mental health team: "Explanatory model" or "explanatory map." Social Science and Medicine, 53(4), 465-476.

Yeh, E. A. (1996). Pseudoseizures in social and cultural context. Transcultural Psychiatry, 33(1), 3-32.

Claudia Lang, PhD, is a postdoctoral research student in the Institute of Social and Cultural Anthropology of Ludwig-Maximilians-University, Munich. Dr. Claudia Lang specializes in cultural, medical and psychiatric anthropology in South Asia. She is currently investigating local understandings and translations of 'depression' and other mental health problems in biomedical and Ayurvedic psychiatry and in ritual healing. She is further working on subjectivities of depression. Address: Institute of Social and Cultural Anthropology, Ludwig-Maximilians-University, Oettingenstr. 67, 80538 Munich, Germany. email: Claudia.lang@ ethnologie.lmu.de 